\title{
Study of the Physical Nature of the Electric Arc in Power Oil-Filled Transformers
}

\section{ISSN: 2576-8840}

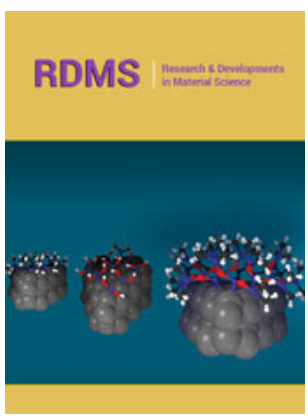

*Corresponding author: Hruntovich NV Department of Power Supply, Sukhoi State Technical University of Gomel, Republic of Belarus

Submission: 些 May 04, 2020

Published: 温 May 15, 2020

Volume 13 - Issue 3

How to cite this article: Hruntovich NV, Zhuk YA. Study of the Physical Nature of the Electric Arc in Power OilFilled Transformers. Res Dev Material Sci. 13(3). RDMS.000815. 2020 DOI: 10.31031/RDMS.2020.13.000815

Copyright@ Hruntovich NV, This article is distributed under the terms of the Creative Commons Attribution 4.0 International License, which permits unrestricted use and redistribution provided that the original author and source are credited.

\section{Hruntovich NV* and Zhuk YA}

Department of Power Supply, Sukhoi State Technical University of Gomel, Republic of Belarus

\section{Opinion}

It is known that during chromatographic control of combustible gases dissolved in oil, partial discharges and an electric arc are detected. Partial discharges with a low energy density correspond to the following ratios of combustible gases: $\mathrm{C} 2 \mathrm{H} 2 / \mathrm{C} 2 \mathrm{H} 4<0.1$; $\mathrm{CH} 4 /$ $\mathrm{H} 2<0.1 ; \mathrm{C} 2 \mathrm{H} 4 / \mathrm{C} 2 \mathrm{H} 6<1$. An electric arc occurs with the following ratios of combustible gases: $\mathrm{C} 2 \mathrm{H} 2 / \mathrm{C} 2 \mathrm{H} 4=0.1 \div 3 ; \mathrm{CH} 4 / \mathrm{H} 2=0.1 \div 1 ; \mathrm{C} 2 \mathrm{H} 4 / \mathrm{C} 2 \mathrm{H} 6>3$.

The conditions for the formation of an electric arc in transformers, as well as the physical processes of the formation of partial discharges, are insufficiently studied. There are certain reasons for this. Firstly, not all experts consider partial discharges a dangerous defect. Secondly, in some regulatory documents it is recommended to measure partial discharges once every eight years. Well-known Russian experts in the field of technical diagnostic power transformers are put partial discharges on the eighth place in ranking controlled parameters of the diagnostic value. At the same time, chromatographic analysis of dissolved gases comes first. Undoubtedly, the chromatographic control of combustible gases in oil allows one to obtain integral information about local overheating and the presence of partial discharges. But if we add to this the speed of development of the defect and the magnitude of the damage, then partial discharges must come first place.

Studies in the laboratories of the university and at transformer substations showed that partial discharges as a diagnostic parameter and defect simultaneously have their own characteristics:

A. Non-stationary nature at the place of occurrence (floating defect), in amplitude and frequency of the signal;

B. Partial discharges contribute to the rapid formation and increase of combustible gases in the oil;

C. Under certain conditions, partial discharges pass into an electric arc with large damage to transformers;

D. Partial discharges pose a great danger to isolation due to its rapid destruction in local zones with subsequent breakdown of insulation.

A plastic vessel with 1 liter transformer oil and mechanical oil contaminants were used to study partial discharges The studies were carried out on the AID-70 M high-voltage test setup, an M4202 partial discharge probe (Lemke 5), a Tangens-3M instrument, and a VERTEX 70 Fourier spectrometer (BRÜKER, Germany). Effect of the composition and the amount of solids on the intensity of the partial discharge was investigated. 
Visually, using the partial discharge probe M4202 (Lemke 5) and the calculations of the ratios of combustible gases, the effect of mechanical impurities on the intensity of partial discharges was confirmed. Based on the theory of similarity, an analysis was made of the conditions for the occurrence of lightning - an intense discharge of atmospheric electricity between the cloud and the earth, which scientists have studied quite deeply. It turns out that the laws of electricity in the atmosphere and transformer oil are similar. Certain conditions are necessary for the formation of an electric discharge (electric arc). These conditions are defined. The consequence of an electric arc in a transformer is the ignition of oilfilled bushings and the destruction of bushings with RIP insulation.

For possible submissions Click below: 